\title{
Profiling of Pro-Inflammatory Cytokines in Radiation Induced Oral Mucositis (RIOM) among Indian patients
}

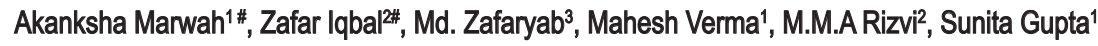 \\ 1'Department of Oral Medicine \& Radiology, Maulana Azad Institute of Dental Sciences, BSZ Marg, New Delhi - 110002, India \\ ${ }^{2}$ Department of Biosciences, Jamia Millia Islamia, New Delhi-110025, India \\ \#Both authors contributed equaly
}

\begin{abstract}
Radiation-induced oral mucositis (RIOM) is aimed at evaluating the expression of NF- $\mathrm{K} \beta, \mathrm{IL}-1 \mathrm{a}$, IL-6, IL-8 and TNF-a in patients with RIOM so as to validate their role in the pathobiology of the disease. Blood samples were collected and serum of 45 patients isolated with clinical signs and symptoms of mucositis and 10 healthy controls were also included in the study. The expression level of NF-K $\beta$, IL-1a, IL-6, LL-8, TNF-a was investigated using ELISA. Mann Whitney U test was applied to find the significance of the expression of these markers in RIOM patients as compared to normal healthy controls and significant expression $(P<0.05)$ for NF-K $\beta, I L-6$, TNF- $\alpha$ and non-significant expression ( $P>0.05)$ IL-1a and IL-8 was found. No significant change in the expression level of the cytokines was observed for patients undergoing chemotherapy and radiation therapy as well as those receiving only the radiation therapy as a part of their treatment. We have also found less expression in grade 1 of mucositis as compared to grade 4. Pro- inflammatory cytokines indeed play a vital role in the pathogenesis as well as progression of RIOM.
\end{abstract}

Keywords: Mucositis, NF-kß, Proinflammatory cytokines, Radiation therapy

Received for publication: December 29, 2016 Accepted: July 26, 2017

Correspondence to: Dr. M.M.A Rizvi, Professor Department of Biosciences, Jamia Millia Islamia, New Delhi-110025, India. Email id: rizvijmi@gmail.com Contact number: +91-9911661657

\section{Introduction}

Incidence of various cancer types have been reported to increase multifold in recent times ${ }^{1,2}$ with oral mucositis being one of the most recurrent, symptomatic, and troubling complication of the conventional cancer treatments, viz., radiation and/or chemotherapy ${ }^{3,4}$. It can be defined as inflammatory and/or ulcerative lesions of the oral and/or gastrointestinal tract usually caused by cancer therapies ${ }^{5}$. It is mostly associated with pain and increased risk of infection thus leading to impaired nutritional status and inadequate hydration ${ }^{3,6}$. It may also be associated with increased risk for poorer outcome of cancer treatment due to the need for treatment interruption in some patient cohorts ${ }^{6,7}$. The incidence of oral mucositis can be close to $80 \%$ in patients receiving radiation therapy, with or without chemotherapy having head and neck cancer ${ }^{8,9}$ with $25-45 \%$ of the patients reporting with grade 3 or 4 mucositis ${ }^{10}$.

The process of mucositis occurs in five stages or phases: initiation, message generation, signal amplification, ulceration, and healing ${ }^{11,12}$. There are numerous transcription factors involved in the establishment of mucositis, one of the most important is nuclear factor-kappa $\beta(\mathrm{NF}-\mathrm{K} \beta)$. NF-K $\beta$ activation can upregulate the expression of pro-inflammatory cytokines including tumor necrosis factor- $\alpha$ (TNF- $\alpha$ ), 
interleukin- $1 \alpha$ (IL-1 $\alpha)$, IL-6 and IL- $8^{13,14}$. The increased levels of these cytokines induce inflammatory reactions in oral mucosa and promote the damage of the underlying connective tissues reduce epithelial oxygenation and ultimately result in epithelial basal cell death and injury ${ }^{4,15}$. Since TNF- $\alpha$, IL- $1 \alpha$ and IL- 6 are efficient activators of NF-K $\beta$ and the repeated $N F-\kappa \beta$ activation by them may amplify the mucosal damage in a vicious circle $e^{4,13,14}$ which hence would ultimately lead to the development of mucositis as an after effect of radiation therapy.

The aim of this study is to analyze the cytokine expression of NF-k $\beta$ and its associated cytokines (IL-1 $\alpha$, IL-6, IL-8, TNF- $\alpha$ ) in the serum of patients with radiation induced oral mucositis after undergoing radiation therapy for head and neck cancers so as to validate their role in the pathobiology of the disease.

\section{Materials and Methods}

\section{Sample selection}

45 patients (Group I) reported to Department of Radiation therapy, LNJP Hospital, Delhi with head \& neck cancer undergoing radiation therapy with/without chemotherapy and showing clinical symptoms of oral mucositis were selected for the study. Around $2 \mathrm{~mL}$ blood was collected and centrifuged at 5000rpm. Their serum was separated and stored at $-80^{\circ} \mathrm{C}$ until further use. Serum samples from 10 healthy volunteers with no history of cancer or previous radiation therapy served as the control group (Group II). Approval from institutional ethical committee \& prior informed consent was taken from all the patients.

\section{Patient Characteristics}

In group I 33 male and 12 female with a mean age of 49.82 years were enrolled. Group II included 10 healthy controls (5 male and 5 female) with a mean age of 44.9 years with no prior history of undergoing any radiation treatment.

39 out of 45 patients developed symptoms of mucositis during /after the treatment therapy while about 6 patients showed no visible signs of any such complications (grade 0 ). 27 out of 39 patients had developed early signs of mucositis (grades $1 \& 2$ ) with symptomatic redness and erythema, loss of taste, mouth dryness. 12 out of 39 patients had developed severe signs of mucositis (grades $3 \& 4$ ) during the course of their treatment, with painful contiguous pseudo membraneous lesions developed along with associated dysphagia and decreased oral intake. 26 out of 45 patients had undergone chemotherapy along with the radiation treatment, while 19 out of 45 patients undertook just the radiation therapy as a part of their cancer treatment.

\section{Detection of serum Levels of NF-K $\beta$, IL-1a, IL-6, IL-8 and TNF-a}

The concentration of the studied biomarkers were assessed in the serum collected from patients and healthy subjects by ELISA by using a commercially available enzyme-linked immunosorbent assay (ELISA) kit (Ray Biotech, Inc.). This assay employs the quantitative sandwich enzyme immunoassay technique performed using human recombinant standards according to the manufacturer's instructions. A monoclonal antibody specific for the respective cytokines was precoated onto the microplate. Standards and samples (100 $\mu \mathrm{L}$ each) were pipetted into the wells in duplicate and incubated for $2.5 \mathrm{hrs}$. so that any of the proteins, i.e., NF-K $\beta$, IL- $1 \alpha$, IL- 6 , IL- 8 and TNF- $\alpha$, if present in the sample can bind to the immobilized antibody. After washing away any unbound substances biotinylated antibody $(100 \mu \mathrm{L})$ was added to the wells and incubated again for an hour. After washing $100 \mu \mathrm{L}$ of HRP-streptavidin solution was added to each well followed by $45 \mathrm{~min}$. incubation. Following a wash to remove any unbound antibody-enzyme reagent a substrate solution $(100 \mu \mathrm{L})$ was added to the wells and incubated for $30 \mathrm{~min}$. The color developed in proportion to the amount of protein bound to the immobilized antibody in the initial step. The yellow color development was stopped and the intensity of the blue color was measured by determining its absorbance at $450 \mathrm{~nm}$ using an ELISA plate reader (Bio-Rad). The concentration of proteins in the samples was calculated from the standard curve and the results were presented in picogram per milliliter $(\mathrm{pg} / \mathrm{mL})$ for IL-1 $\alpha$, IL-6, IL- 8 and TNF- $\alpha$ and in nanogram per milliliter $(\mathrm{ng} / \mathrm{mL})$ for NF-k $\beta$. The standard curves for NF-K $\beta$, IL- $1 \alpha$, IL-6, IL- 8 and TNF- $\alpha$ ranged from $(0-500$ $\mathrm{ng} / \mathrm{mL}),(0-300 \mathrm{pg} / \mathrm{mL}),(0-1000 \mathrm{pg} / \mathrm{mL}),(0-1000 \mathrm{pg} / \mathrm{mL})$ and $(0-600 \mathrm{pg} / \mathrm{mL})$ respectively.

\section{Statistical Analysis}

Data were analyzed with descriptive statistical methods (frequency percentage and mean \pm standard deviation) and Mann-Whitney $U$ test (a non-parametric method) using SPSS (statistical package for social sciences) software version 19.0 for windows. Statistical significance was defined at $\mathrm{P}<0.05$.

\section{Results}

\section{Serum levels of NF-k $\beta$ and pro-inflammatory cytokines}

Detectable levels of NF-k $\beta$, IL- $1 \alpha$, IL-6, IL-8 and TNF- $\alpha$ proteins were present in serum samples obtained from the control group (group II). Serum levels of NF-k $\beta$, IL- $1 \alpha$, IL-6, IL- 8 and TNF- $\alpha$ were elevated in $100 \%(45 / 45), 60 \%(27 / 45)$, $100 \%(45 / 45), 53.34 \%(24 / 45), 100 \%(45 / 45)$ of the patients respectively as compared to their concentration in the serum of healthy subjects. The mean values of NF-K $\beta(262.65 \pm 169.91 \mathrm{ng} /$ $\mathrm{ml})$, IL-6 (112.56 $\pm 309.07 \mathrm{pg} / \mathrm{ml})$ and TNF- $\alpha(372.28 \pm 472.39$ $\mathrm{pg} / \mathrm{ml})$ in serum of the patients were significantly $(\mathrm{p}<0.05)$ higher in comparison with the values obtained from control subjects that were $25.66 \pm 9.502 \mathrm{ng} / \mathrm{ml}, 4.880 \pm 2.95 \mathrm{pg} / \mathrm{ml}$ and $12.00 \pm 7.0590 \mathrm{pg} / \mathrm{ml}$ for NF-K $\beta$, IL- 6 and TNF- $\alpha$, respectively, as revealed by Mann-Whitney $U$ test $^{2}$ (Figure 1)

Mean values for IL-1 $\alpha(38.919 \pm 69.99 \mathrm{pg} / \mathrm{ml})$ and IL-8 $(53.38 \pm 137.88 \mathrm{pg} / \mathrm{ml})$ were also increased as compared to their values in the control group (IL- $1 \alpha=26.790 \pm 10.055 \mathrm{pg} / \mathrm{ml}$ and IL-8 $=8.690 \pm 2.534 \mathrm{pg} / \mathrm{ml}$ ) but statistically a non-significant difference was obtained between the two groups (Figure 1). 
Table 1 - Clinical detail of patients.

\begin{tabular}{|c|c|c|c|c|c|c|c|}
\hline S.No. & Sex & Age & Tumour Type & Radiation Therapy & Chemo-therapy & Mucositis & Grade \\
\hline 1 & $\mathrm{~F}$ & 40 & Tongue & Yes & No & No & 0 \\
\hline 2 & M & 30 & Tongue \& fossa & Yes & Yes & Yes & 4 \\
\hline 3 & $\mathrm{~F}$ & 64 & Larynx & Yes & Yes & Yes & 1 \\
\hline 4 & M & 60 & Tonsil-R & Yes & Yes & Yes & 1 \\
\hline 5 & $\mathrm{~F}$ & 55 & Tonsil-L & Yes & Yes & Yes & 1 \\
\hline 6 & M & 26 & Buccal mucosa & Yes & No & Yes & 2 \\
\hline 7 & M & 40 & Gingivae & Yes & No & Yes & 2 \\
\hline 8 & M & 65 & Base of tongue & Yes & Yes & Yes & 4 \\
\hline 9 & M & 50 & Soft palate & Yes & No & Yes & 3 \\
\hline 10 & M & 48 & Larynx & Yes & Yes & No & 0 \\
\hline 11 & $\mathrm{~F}$ & 60 & Base of tongue & Yes & Yes & Yes & 3 \\
\hline 12 & M & 35 & Base of tongue & Yes & No & Yes & 3 \\
\hline 13 & M & 76 & Base of tongue & Yes & No & No & 0 \\
\hline 14 & $\mathrm{~F}$ & 45 & Tongue & Yes & Yes & Yes & 3 \\
\hline 15 & M & 65 & Body of tongue & Yes & Yes & Yes & 1 \\
\hline 16 & M & 40 & Pharynx & Yes & Yes & Yes & 1 \\
\hline 17 & M & 68 & Tonsil & Yes & Yes & Yes & 1 \\
\hline 18 & M & 32 & $\begin{array}{l}\text { Buccal mucosa \& } \\
\text { border of tongue }\end{array}$ & Yes & Yes & Yes & 1 \\
\hline 19 & M & 63 & Soft palate & Yes & No & No & 0 \\
\hline 20 & $\mathrm{~F}$ & 45 & Larynx & Yes & Yes & Yes & 1 \\
\hline 21 & M & 28 & Tongue & Yes & Yes & Yes & 3 \\
\hline 22 & M & 45 & Nasopharynx & Yes & Yes & Yes & 1 \\
\hline 23 & $M$ & 36 & $\begin{array}{l}\text { Buccoalveolar } \\
\text { region- } R\end{array}$ & Yes & No & Yes & 4 \\
\hline 24 & M & 22 & $\begin{array}{l}\text { Buccal mucosa \& } \\
\text { border of tongue }\end{array}$ & Yes & Yes & Yes & 1 \\
\hline 25 & M & 40 & Larynx & Yes & Yes & Yes & 1 \\
\hline 26 & M & 62 & Larynx & Yes & Yes & Yes & 1 \\
\hline 27 & $\mathrm{~F}$ & 50 & Right tonsil & Yes & Yes & Yes & 1 \\
\hline 28 & M & 68 & Left tonsil & Yes & No & No & 0 \\
\hline 29 & M & 70 & Buccal mucosa-left & Yes & No & Yes & 1 \\
\hline 30 & M & 63 & $\begin{array}{l}\text { Buccal muco- } \\
\text { sa-right }\end{array}$ & Yes & No & Yes & 3 \\
\hline 31 & M & 55 & Base of tongue & Yes & Yes & Yes & 1 \\
\hline 32 & M & 54 & Buccal mucosa-left & Yes & No & Yes & 3 \\
\hline 33 & $\mathrm{~F}$ & 55 & $\begin{array}{l}\text { Recurrent adenoid } \\
\text { cystic carcinoma } \\
\text { with secondary } \\
\text { metastasis }\end{array}$ & Yes & Yes & Yes & 1 \\
\hline 34 & M & 62 & Base of tongue & Yes & No & No & 0 \\
\hline 35 & $\mathrm{~F}$ & 48 & Tonsil & Yes & No & Yes & 1 \\
\hline 36 & M & 27 & Buccal mucosa & Yes & Yes & Yes & 3 \\
\hline 37 & $\mathrm{~F}$ & 55 & Tongue & Yes & Yes & Yes & 1 \\
\hline 38 & M & 71 & Tongue & Yes & Yes & Yes & 1 \\
\hline 39 & $\mathrm{~F}$ & 43 & Larynx & Yes & No & Yes & 1 \\
\hline 40 & $\mathrm{~F}$ & 45 & Tonsil- left & Yes & No & Yes & 2 \\
\hline 41 & M & 42 & Floor of mouth & Yes & Yes & Yes & 2 \\
\hline 42 & M & 65 & Soft palate & Yes & No & Yes & 2 \\
\hline 43 & M & 40 & Base of tongue & Yes & Yes & Yes & 2 \\
\hline 44 & M & 53 & Larynx & Yes & No & Yes & 2 \\
\hline 45 & M & 36 & Base of tongue & Yes & No & Yes & 4 \\
\hline
\end{tabular}

\begin{tabular}{|c|c|c|c|c|c|c|}
\hline \multirow{3}{*}{ Cytokines } & \multicolumn{5}{|c|}{ Mean values of Cytokine concentration in serum of mucositis patients and healthy controls. } & \multirow{3}{*}{ P-value } \\
\hline & \multicolumn{2}{|c|}{ Mean \pm S.D. } & \multicolumn{2}{|c|}{ Median } & \multirow{2}{*}{$\begin{array}{l}\text { Percentage of patients showing } \\
\text { upregulation in mucositis group } \\
\text { as compared to control group }\end{array}$} & \\
\hline & $\begin{array}{l}\text { RIOM patients } \\
\text { (Group I) }\end{array}$ & $\begin{array}{c}\text { Control group } \\
\text { (Group II) }\end{array}$ & $\begin{array}{l}\text { RIOM patients } \\
\text { (Group I) }\end{array}$ & $\begin{array}{c}\text { Control group } \\
\text { (Group II) }\end{array}$ & & \\
\hline $\mathrm{NF}-\mathrm{k} \beta$ (ng/ml) & $262.65 \pm 169.91$ & $25.66 \pm 9.502$ & 240 & 28.00 & $100 \%(45 / 45)$ & $.001(\mathrm{~S})$ \\
\hline $\mathrm{IL}-1 \mathrm{a}(\mathrm{pg} / \mathrm{ml})$ & $38.919 \pm 69.99$ & $26.7907 \pm 10.5$ & 29 & 25.7 & $60 \%(27 / 45)$ & $.115(\mathrm{NS})$ \\
\hline $\mathrm{IL}-6(\mathrm{pg} / \mathrm{ml})$ & $112.56 \pm 309.7$ & $4.880 \pm 2.95$ & 45.7 & 5.450 & $100 \%(45 / 45)$ & $.001(S)$ \\
\hline $\mathrm{IL}-8$ (pg/ml) & $53.38 \pm 137.88$ & $8.690 \pm 2.354$ & 9.8 & 9.050 & $53.34 \%(24 / 45)$ & .952 (NS) \\
\hline TNF-a (pg/ml) & $372.28 \pm 472.39$ & $12.00 \pm 7.0590$ & 256 & 9.100 & $100 \%(45 / 45)$ & $.001(\mathrm{~S})$ \\
\hline
\end{tabular}




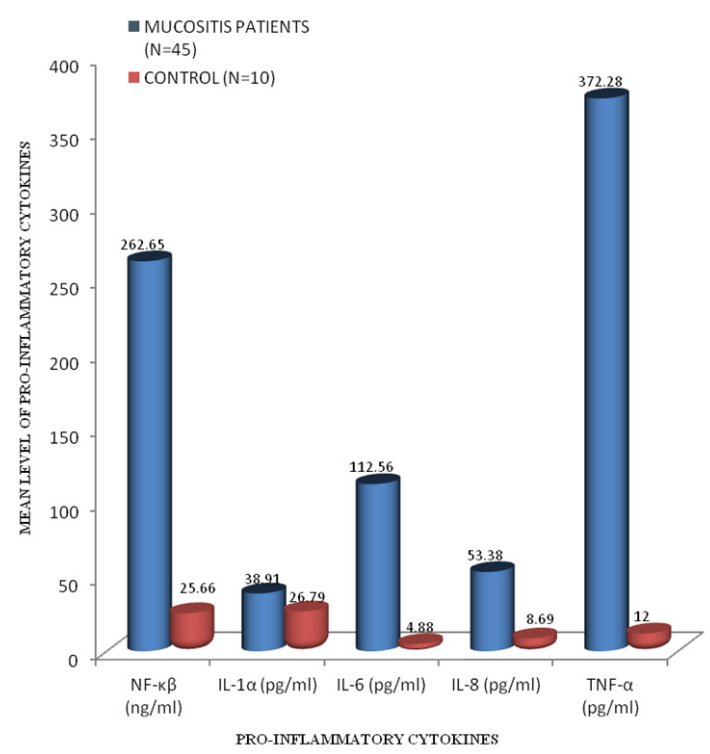

Fig. 1 - Mean serum concentrations of pro-inflammatory cytokines in control subjects and mucositis patients.

On comparing the expression level of different proinflammatory cytokines of the patients receiving chemotherapy along with the radiation therapy and those undergoing just the radiation therapy no significant difference $(p>0.05)$ was observed in the expression of these cytokines as depicted in figure 2 thus implying that radiation and chemotherapy treatments whether given alone or in combination as a part of treatment regimen for head and neck cancer have almost the same effect on the expression level of the studied pro-inflammatory cytokines.

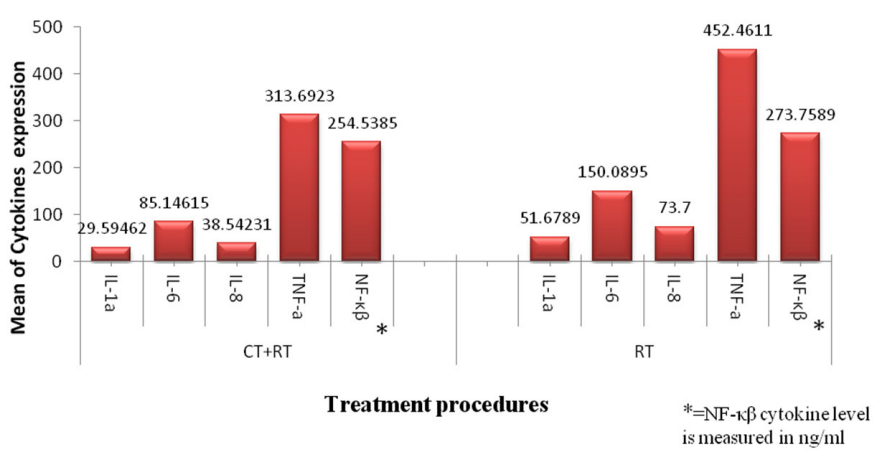

Fig. 2 - Graph depicting the mean of expression of different pro-inflammatory cytokines for patients undergoing radiation therapy along with chemotherapy $(\mathrm{CT}+\mathrm{RT})$ and those undergoing only the radiation therapy (RT).

Furthermore, analyzing the expression of different cytokines (TNF- $\alpha$, NF-K $\beta$, IL-8, IL-6, IL- $\alpha$ ) with respect to the different grades of mucositis we have found that the expression level of studied cytokines increases with the progression of the mucositis (grade 1 to grade 4 ) as depicted in figure 3.

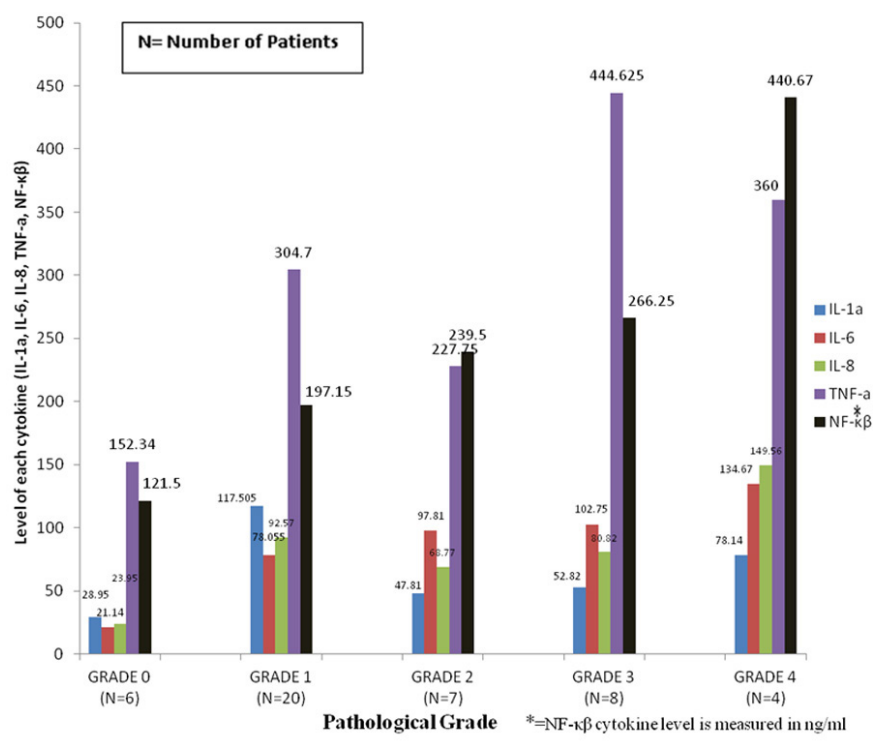

Fig. 3 - Comparison of expression of different cytokines-NF-k $\beta$, IL-1 $\alpha$, IL-6, IL-8 and TNF- $\alpha$ in different grades of mucositis.

\section{Discussion}

Oral mucositis is an undesirable painful outcome endured by patients receiving radiation and/or chemotherapy for head and neck cancer treatment. Radiation and chemotherapy are effective activators of several pathways in endothelia, fibroblasts and epithelia thus leading to the production and upregulation of certain pro inflammatory cytokines ${ }^{16,17}$ which have been reported to play an important role during inflammation and tissue damage ${ }^{18}$.

The present study examined the expression level of NF-K $\beta$ and its associated pro-inflammatory cytokines (IL-6, TNF- $\alpha$, IL-1 $\alpha$ and IL-8) in head and neck cancer patients undergoing radiation and/or chemotherapy as a part of their treatment. Our results showed a significant increase in the expression of NF- $\mathrm{k} \beta$, IL- 6 and TNF- $\alpha(P$ value $<0.05)$ in the serum of all the patients enrolled for the study as compared to the control group. However, nearly $60 \%$ and $52.5 \%$ of the patients showed an increase in the expression of IL- $1 \alpha$ and IL- 8 (P value $>0.05$ ) as compared to the control group (healthy volunteers).

A marginal increase has been seen in the expression of NF-K $\beta$ due to the exposure of the tissue to chemotherapy or radiation therapy causing the production of reactive oxygen species (ROS) that ultimately results in tissue injury and cell death ${ }^{4,11,14,16}$. Previous studies have reported the transcription factor NF-K $\beta$ as being a regulator of inflammation signal and immunity as well as also being involved in the progression of mucositis $^{4,11}$. NF-K $\beta$ regulates the expression of approximately 200 genes many of which may play the role in the pathogenesis of mucositis ${ }^{4,13,19}$ including those encoding COX-2 ${ }^{15,19-21}$ and proinflammatory cytokines such as TNF- $\alpha$, IL-6, and IL-1 $\beta^{4,11,14,22}$. COX-2 intensifies and prolongs mucositis by interacting with a variety of apoptotic pathways and by providing positive feedback to NF-K $\beta$. The increase in the expression of COX-2 can be an 
initial sign of the inflammatory cascade which leads to the production of prostaglandins and further tissue damage $e^{4,11,15,19}$.

Further, upregulation in the expression of proinflammatory cytokines by the action of NF-K $\beta$ triggers the initiation of various pathways that damage epithelial cells and surrounding fibroblasts. The feedback loop formed between various proinflammatory cytokines such as TNF- $\alpha$ and NF-K $\beta$ promotes the cycle of inflammation, pain, and functional impairment ${ }^{11,13,14,17,23,24}$. The presence of TNF- $\alpha$ has been reported by previous studies related to the stimulation of early damage to connective tissue and endothelium thus initiating mesenchymal-epithelial signaling and reducing epithelial oxygenation ultimately resulting in epithelial basal cell death and injury ${ }^{11,15}$.

Several studies have also reported the increase in the expression of IL-6 and IL- 8 as a downstream product of NF-K $\beta$ activation. The upregulation of these proinflammatory cytokines has been known to mediate neutrophil extravasation and tissue infiltration during inflammation thereby playing an important role in the migration of leukocytes into the site of inflammation ${ }^{15,25-27}$. The amplification of these biological events via positive feedback loops as well as stimulation by bacterial cell wall products results in the widespread tissue damage as seen in the clinical setting as ulceration. This ulcerative phase is primarily responsible for the main clinical symptoms of mucositis (pain, inflammation, and loss of function) $)^{11,17,28}$.

A study by Ong et al., in 2010 partially related to our study was done to characterize the expression of pro-inflammatory cytokines in the gastrointestinal tract using a rat model of fractionated radiotherapy-induced toxicity. Ong found that a significant upregulation of IL-1 $\beta$, IL-6 and TNF mRNA levels in the jejunum and colon thus concluding the role of pro-inflammatory cytokines in radiotherapy-induced gastrointestinal mucositis ${ }^{22}$.

Another study ${ }^{29}$ implicated the role of NF-K $\beta$, proinflammatory cytokines, COX and MMPs in the pathogenesis of mucositis as these factors were being expressed at elevated levels in both serum and tissue following radiotherapy and/or chemotherapy ${ }^{29}$. Our findings have also been supported by studies done on an animal model by Logan et al that reported the changes in the expression of NF-K $\beta$, TNF, IL- $1 \beta$ and IL- 6 in the mucosa and serum following chemotherapy orated a statistically increased oral mucosal $\operatorname{stain}^{17,30}$. Another study done by Logan et al., on a human biopsy demonstrated the increased level of NF-K $\beta$ and COX-2 in patients with chemotherapy as well as radiotherapy ${ }^{17}$. However, Ikebe et al., observed the expression of NF-K $\beta$ to be reduced after chemo radiotherapy and concluded that the vulnerability of oral mucosa undergoing chemo radiation may be associated with reduced NF-K $\beta$ expression and impaired growth activity ${ }^{31}$. The role of systemic inflammation in the development of mucositis was further supported by studies showing that the therapy targeted to alter cytokine expression is able to modify the course of mucositis ${ }^{32}$. Animal ${ }^{33}$ and human studies ${ }^{34}$ have demonstrated a decrease in the occurrence or severity of mucositis following the administration of TNF inhibitors.

The cytokines are reported to be unregulated when individually subjected to radiation treatment ${ }^{11,15,19,20,22,35}$ and chemotherapy ${ }^{24,30,36-41}$. However, no such studies have been made on patients undergoing chemotherapy and radiation therapy simultaneously. We evaluated the level of cytokines (TNF- $\alpha$, NF$\mathrm{K} \beta, \mathrm{IL}-8, \mathrm{IL}-6, \mathrm{IL}-\alpha)$ in patients receiving radiation treatment and those receiving chemotherapy along with the radiation treatment. This study for the first time reveals that there is no significant variation in the levels of cytokines in the patients undergoing radiation as well as chemotherapy and those undergoing just the radiation treatment. This finding demonstrated that the severity of mucositis does not depend on the type of treatment (radiation and/or chemotherapy) being administered to the patient and that both the treatments have more or less the same effect on the level of these cytokines.

We further correlate our study to the clinic-pathological parameters (grading of mucositis). Interestingly we found that advanced stage (grade 4) mucositis demonstrated the increase in the expression of cytokines (TNF- $\alpha$, NF-K $\beta$, IL-8, IL-6, IL- $\alpha$ ) as compared to early stage (grade o \& 1) of mucositis as well as healthy control. This finding was supported by Ong et al., who also reported the importance of these proinflammatory cytokines in the development and severity of radiotherapy induced gastrointestinal mucositis in rats ${ }^{22}$.

It is therefore very clear to understand that inflammatory cytokines (TNF- $\alpha$, NF-K $\beta$, IL-8, IL-6, IL- $\alpha$ ) play a vital role in the progression of radiation induced oral mucositis.

\section{Conclusion}

On the basis of above findings, we are able to conclude that NF-K $\beta$ and its associated cytokines (TNF- $\alpha$, IL-8, IL-6, IL- $\alpha$ ) are involved in the pathogenesis of radiation induced oral mucositis. We further provide evidence for the association of these pro-inflammatory cytokines with the progression of this disease into more advanced stages. Continued research will undoubtedly provide a better understanding of the dynamics leading to mucosal injury and to more effective measures for prevention and treatment. Refinement of the five-stage model of mucositis pathogenesis may aid in the rational use of therapies to maximize their efficacy. Further studies are necessary to elucidate the exact role of these cytokines as biomarkers for this disease.

\section{Acknowledgement}

This work has been supported by grants from University Grants Commission (UGC), Bahadur Shah Zafar Marg, Delhi-110 002, India.

\section{Conflict of Interest}

None Declared.

\section{References}

1. Rizvi MM, Alam MS, Ali A, Mehdi SJ, Batra S, Mandal AK. Aberrant promoter methylation and inactivation of PTEN gene in cervical carcinoma from Indian population. J Cancer Res Clin Oncol. 2011 Aug;137(8):1255-62. doi: 10.1007/s00432-011-0994-0.

2. Rizvi MM, Ali A, Mehdi SJ, Saluja SS, Mishra PK. Association of 
epigenetic alteration in PTEN gene with colorectal cancer progression among Indian population. Int J Colorectal Dis. 2013 Feb;28(2):283-4. doi: 10.1007/s00384-012-1482-y.

3. Dirix P, Nuyts $S$, Van den Bogaert W. Radiation-induced xerostomia in patients with head and neck cancer: a literature review. Cancer. 2006 Dec;107(1):2525-34.

4. Sonis ST, Elting LS, Keefe D, Peterson DE, Schubert M, Hauer-Jensen $\mathrm{M}$, et al., Perspectives on cancer therapy-induced mucosal injury: pathogen?esis, measurement, epidemiology, and consequences for patients. Cancer. 2004 May;100(9 Suppl):1995-2025.

5. Peterson DE, Bensadoun RJ, Roila F; ESMO Guidelines Working Group. Management of oral and gastrointestinal mucositis: ESMO Clinical Practice Guidelines. Ann Oncol. 2011 Sep;22 Suppl 6:vi78-84. doi: 10.1093/annonc/mdr391. Erratum in: Ann Oncol. 2012 Mar;23(3):810.

6. Peterson DE. New Strategies for Management of Oral Mucositis in Cancer Patients. J Support Oncol. 2006 Feb;4(2 Suppl 1):9-13.

7. Pico JL, Avila-Garavito A, Naccache P. Mucositis: its occurrence, consequences, and treatment in the oncology setting. Oncologist. 1998;3(6):446-51.

8. Trotti A, Bellm LA, Epstein JB, Frame D, Fuchs HJ, Gwede CK, et al., Mucositis incidence, severity and associated outcomes in patients with head and neck cancer receiving radiotherapy with or without chemotherapy: A systematic literature review. Radiother Oncol. 2003 Mar;66(3):253-62.

9. Silverman S Jr. Diagnosis and management of oral mucositis. J Support Oncol. 2007 Feb;5(2 Suppl 1):13-21.

10. Rubenstein EB, Peterson DE, Schubert M, Keefe D, McGuire D, Epstein J, Elting LS, Fox PC, Cooksley C, Sonis ST; Mucositis Study Section of the Multinational Association for Supportive Care in Cancer; International Society for Oral Oncology. Clinical practice guidelines for the prevention and treatment of cancer therapy-induced oral and gastrointestinal mucositis. Cancer. 2004 May 1;100(9 Suppl):2026-46.

11. Sonis ST, O'Donnell KE, Popat R, Bragdon C, Phelan S, Cocks D, et al. The relationship between mucosal cyclooxygenase-2 (COX-2) expression and experimental radiation-induced mucositis. Oral Oncol. 2004 Feb;40(2):170-6.

12. Dorr W, Hamilton CS, Boyd T, Reed B, Denham JW. Radiation-induced changes in cellularity and proliferation in human oral mucosa. Int J Radiat Oncol Biol Phys. 2002 Mar;52(4):911-7.

13. Sonis ST. The biologic role for nuclear factor-kappaB in disease and its potential involvement in mucosal injury associated with anti-neoplastic therapy. Crit Rev Oral Biol Med. 2002;13(5):380-9.

14. Sonis ST. Pathobiology of Oral Mucositis: novel insights and opportunities. J Support Oncol. 2007 Oct;5(9 Suppl 4):3-11.

15. Yeoh ASJ, Bowen JM, Gibson RJ, Keefe DM. Nuclear factor $k B$ (NFKB) AND cyclooxygenase-2 (Cox-2) expression in the irradiated colorectum is associated with subsequent histopathological changes. Int. J. Radiation Oncology Biol. Phys. 2005 Dec;63(5):1295-303.

16. Satheesh Kumar PS. Radiation Mucositis. In: Racz GB, Noe CE, editors. Pain Management - Current Issues and Opinions. InTech. Chapter 22. ISBN: 2012.978-953-307-813-7. Available from: https://www.intechopen. com/books/pain-management-current-issues-and-opinions/radiationmucositis.

17. Logan RM, Gibson RJ, Sonis ST, Keefe DM. Nuclear factor-kappaB (NFkappaB) and cyclooxygenase-2 (COX-2) expression in the oral mucosa following cancer chemotherapy. Oral Oncol. 2007 Apr;43(4):395-401.

18. Sultani M, Stringer AM, Bowen JM, Gibson RJ. Anti-Inflammatory Cytokines: Important Immunoregulatory Factors Contributing to Chemotherapy-Induced Gastrointestinal Mucositis. Chemother Res Pract. 2012;2012:490804. doi: 10.1155/2012/490804.

19. Yeoh A, Gibson R, Yeoh E, Bowen J, Stringer A, Giam K, et al. Radiation therapy-induced mucositis: relationships between fractionated radiation, NF-kB, COX-1, and COX-2. Cancer Treat Rev. 2006 Dec;32(8):645-51.
20. Brach MA, Hass R, Sherman ML, Gunji H, Weichselbaum R, Kufe D. lonizing radiation induces expression and binding activity of the nuclear factor, kappa B. J Clin Invest. 1991 Aug;88(2):691-5.

21. Lee SJ, Dimtchev A, Lavin MF, Dritschilo A, Jung M. A novel ionizing radiation-induced signaling pathway that activates the transcription factor NF-kappaB. Oncogene. 1998 Oct;17(14):1821-6.

22. Ong ZY, Gibson J, Bowen JM, Stringer AM, DarbyJM, Logan RM, et al. Pro-inflammatory cytokines play a key role in the development of radiotherapy-induced gastrointestinal mucositis. Radiat Oncol. 2010 Mar;5:22. doi: 10.1186/1748-717X-5-22.

23. Sonis ST. Mucositis as a biological process: a new hypothesis for the development of chemotherapy-induced stomatotoxicity. Oral Oncol. 1998 Jan;34(1):39-43.

24. Logan RM, Stringer AM, Bowen JM, Gibson RJ, Sonis ST, Keefe DM. Serum levels of NFkappaB and pro-inflammatory cytokines following administration of mucotoxic drugs. Cancer Biol Ther. 2008 Jul;7(7):113945.

25. Kelly CP, Keates S, Siegenberg D, Linevsky JK, Pothoulakis C, Brady HR. IL-8 secretion and neutrophil activation by HT-29 colonic epithelial cells. Am J Physiol. 1994 Dec;267(6 Pt 1):991-7.

26. Campbell BJ, Yu LG, Rhodes JM. Altered glycosylation in inflammatory bowel disease: A possible role in cancer development. Glycoconj. 2001 Nov-Dec;18(11-12):851-8.

27. Ikeda $Y$, Ito M, Matsuu M, Shichijo K, Fukuda E, Nakayama T et al., Expression of ICAM-1 and acute inflammatory cell infiltration in the early phase of radiation colitis in rats. J Radiat Res. 2000 Sep;41(3):279-91.

28. Duncan M, Grant G. Oral and intestinal mu $\urcorner$ cositis—causes and possible treatments. Aliment Pharmacol Ther. 2003 Nov;18(9):853-74.

29. Scully C, Sonis S, Diz PD. Oral mucositis. Oral Dis. 2006 May;12(3):22941.

30. Logan RM, Gibson RJ, Bowen JM, Stringer AM, Sonis ST, Keefe DM Characterisation of mucosal changes in the alimentary tract following administration of irinotecan: implications for the pathobiology of mucositis. Cancer Chemother Pharmacol. 2008 Jun;62(1):33-41.

31. Ikebe T, Yamasakia K, Takamunea $Y$, Nakayamaa H, Shinohara M. Reduced expression of nuclear factor $\mathrm{kB}$ in oral mucosa undergoing preoperative chemoradiotherapy. Oral Science International. 2012 Nov;992):33-7. doi:10.1016/S1348-8643(12)00008-0.

32. Khaw A, Logan R, Keefe D, Bartold M. Radiation-induced oral mucositis and periodontitis - proposal for an inter-relationship. 2014 Apr;20(3):e7-18. doi: 10.1111/odi.12199.

33. Lima V, Brito GA, Cunha FQ, Rebouças CG, Falcão BA, Augusto RF, et al., Effects of the tumour necrosis factor-alpha inhibitors pentoxifylline and thalidomide in short-term experimental oral mucositis in hamsters. Eur J Oral Sci. 2005 Jun;113(3):210-7.

34. Ferra C, de Sanjose S, Lastra CF, Martí F, Mariño EL, Sureda A, et al. Pentoxifylline, ciprofloxacin and prednisone failed to prevent transplant related toxicities in bone marrow transplant recipients and were associated with an increased incidence of infectious complications. Bone Marrow Transplant. 1997 Dec;20(12):1075-80.

35. Yeoh ASJ, Gibson RJ, Yeoh E, Bowen JM, Stringer AM, Giam KA, et al. A novel animal model to investigate fractionated radiotherapy-induced alimentary mucositis: the role of apoptosis, p53, nuclear factor-KB COX-1, and COX-2. Mol Cancer Ther. 2007 Aug;6(8):2319-27.

36. Logan RM, Stringer AM, Bowen JM, Yeoh AS, Gibson RJ, Sonis ST, et al. The role of pro-inflammatory cytokines in cancer treatment-induced alimentary tract mucositis: pathobiology, animal models and cytotoxic drugs. Cancer Treat Rev. 2007 Aug;33(5):448-60.

37. Gibson RJ, Keefe DM, Thompson FM, Clarke JM, Goland GJ, Cummins AG. Effect of interleukin-11 on ameliorating intestinal damage after methotrexate treatment of breastcancer in rats. Dig Dis Sci. 2002 Dec;47(12):2751-7

38. Gibson RJ, Bowen JM, Inglis MR, Cummins AG, Keefe DM. Irinotecan 
causes severe small intestinal damage, as well as colonic damage, in the rat with implanted breast cancer. J Gastroenterol Hepatol. 2003 Sep;18(9):1095-100.

39. Gibson RJ, Bowen JM, Cummins AG, Keefe DM. Relationship between dose of methotrexate, apoptosis, p53/p21 expression and intestinal crypt proliferation in the rat. Clin Exp Med. 2005 Mar;4(4):188-95.

40. Soares PMG, Mota J, Souza EP, Justino PF, Franco AX, Cunha FQ, et al. Inflammatory intestinal damage induced by 5 -fluorouracil requires IL-4. Cytokine. 2013 Jan;61(1):46-9. doi: 10.1016/j.cyto.2012.10.003.

41. Logan RM, Stringer AM, Bowen JM, Gibson RJ, Sonis ST, Keefe $\mathrm{DM}$. Is the pathobiology of chemotherapy-induced alimentary tract mucositis influenced by the type of mucotoxic drug administered? Cancer Chemother Pharmacol. 2009 Jan;63(2):239-51. doi: 10.1007/ s00280-008-0732-8. 